\title{
Statistical Optimisation of Fermentation Media for Novel Clostridium novyi-NT Using Response Surface Methodology.
}

\author{
Kannan Krishnamoorthy ${ }^{1 *}$, Anil Vijay Landge ${ }^{1}$ \\ ${ }^{I}$ Annamalai University Department of Pharmacy - Pharmacy, Tamilnadu, India
}

\begin{abstract}
Clostridial collagenase is recognized as one of the important proteolytic enzymes used in treatment of varieties of fibro-proliferative disorders. The present work aimed to optimise the biomass concentration and collagenase enzyme activity of novel bacilli Clostridium novyi-NT. The response surface methodology tool was used to identify the optimal fermentation parameters. Central composite design (CCD) was applied with respect to three influencing factors - $p H$, proteose peptone and trypticase soya broth. These factors showed significant effect on the overall biomass concentration and collagenase enzyme activity $(p<0.05)$. The maximum biomass concentration in terms of absorbance and collagenase activity (of crude enzyme) was achieved and recorded as $0.8309 \pm 0.0012$ and $298.88 \pm 1.36$ units $/ \mathrm{mg}$ respectively after 22 hours of fermentation period while optimisation of media factors with help of response surface quadratic model. This is the first study to report maximum biomass concentration and collagenase activity by Clostridium novyi-NT till date by combining statistical designs.
\end{abstract}

Keywords: Collagenase, Clostridium novyi-NT, Fibro-proliferative disorders, Response Surface Methodology.

\footnotetext{
*Author for correspondence: egkkannan@yahoo.co.in
} 


\section{INTRODUCTION}

Unlike as mammalian collagenase, bacterial collagenase (or metalloproteases), is one of the features of pathogenic virulence, invades the different segments of helical structure of collagen and converts it into fragments. These collagenases are representative enzymes specifically of Clostridium histolyticum and Pseudomonas aeruginosa type invasive strains ${ }^{1}$. Collagenases are widely used in the treatment of various fibro-proliferative disorders including Peyronie's disease, Dupuytren's disorder and also proved the choice of medicine in treatment of keloid, intervertebral disc hernia, Glaucoma, Vitrectomy and in different burn related wound healing ${ }^{2}$. It is most commonly used in detachment and segregation of tissue cells in medical investigation ${ }^{3}$.

Although bacterial collagenase detected its applications in various disciplines, yield of collagenase production requires to be fabricated to make it economically compatible. Hence it is quite essential to optimize the yield of biomass quantity of specific bacterial culture lead to produce collagenase and its assay in terms of specific activity by employing process improvement strategies ${ }^{4}$. Though various research works have optimized media components and different process parameters in order to increase bacterial collagenase (BC) yield from various sources ${ }^{5,6,7}$ unlike pathogenic nature revealed by different species of Vibrio, Pseudomonas and Clostridum histolyticum and Clostridium perfringens; non-pathogenic species of Clostridium novyi -NT are available with high molecular mass as an important characteristic of bacterial collagenase unlikely in Vibrio, Pseudomonas, Bacilli and other Clostridium species. For instance, the high molecular masses of collagenase ensure effective binding of enzyme with collagen, most likely by the presence of the Collagen Binding Domains ${ }^{8}$ (CBD).

Optimization of processing parameters governs a key role in the innovation of any process task owing to their influence on the economy and efficacy ${ }^{9}$. Designing a particular fermentation medium and conditions is of vital importance for efficient and magnified yield of microbial metabolites as active medicinal products via fermentation process, as it can remarkably affect product yield or concentration and thus cost and ease in further downstream process of separation ${ }^{10}$. Statistical experimental designs are more effective than 'at a time one' method, which is complex, laborious and timeconsuming, specifically in screening of multi-variables, and interactions among all different variables ${ }^{11}$.

Rather, statistical designs impart an efficient and systematic task-plan for assessment of different parameters at a time so that those can be simultaneously studied. Therefore, in recent era number of statistical experimental designs are being utilised to innovate the key factors from a multivariable system because optimization of process via statistical designing not only allows high-speed screening of large experimental domain, but also reveals the role of each components and interactions among themselves ${ }^{12}$.

Response Surface Methodology (RSM) is an efficient tool for optimization of different process parameters that employs data in quantitative manner from a suitable experimental design model to assess and concurrently resolve multivariate equations. A statistical design of experiment such as Central Composite Design (CCD) is usually involved and by at least square technique second-order polynomial is fitted. Normally an equation is employed to explain the test variables, and overall combined effect of all the test variables on the response ${ }^{10}$.

The objectives of this investigation includes optimization of bacterial biomass concentration for highest collagenase production from Clostridium novyi -NT and crude collagenase activity determination with the interrelationship among the media 
ingredients on novel clostridial species using response plots along with designing and optimization of significant factors with application of central composite design (CCD).

\section{MATERIALS AND METHODS}

\section{Microorganism}

Clostridium novyi-NT strain as it is reported ${ }^{13}$ earlier as choice of clostridial strain for industrial collagenase production was used in this study and procured from Lokmangal Biotechnology Institute, Wadala. The culture was maintained on reinforced clostridial media (RCM, Hi-media) slants, transferred and stored at a temperature of $2^{\circ} \mathrm{C}$ to $8^{\circ} \mathrm{C}$ in the refrigerator.

\section{Materials}

All chemicals and media components were analytical grade and procured from the Sisco Research Laboratory, Mumbai.

\section{Culture media and growth conditions}

One litres of fermentation medium ${ }^{14}$ was prepared with the following composition: $1.5 \%$ Trypticase soy broth, 5.0\% Proteose peptone, $80 \mathrm{mg} \mathrm{MgSO}_{4}-7 \mathrm{H}_{2} \mathrm{O}, 1.92 \mathrm{~g}$ $\mathrm{KH}_{2} \mathrm{PO}_{4}, 9.0 \mathrm{~g} \mathrm{Na} 2 \mathrm{HPO}_{4}, 5.0 \mathrm{ml}$ vitamin concentrate $(100 \mathrm{ml}$. of this vitamin concentrate contains: $20 \mathrm{mg}$ each of Calcium pantothenate, nicotinic acid, pyridoxine, pimelic acid, thiamine and $2.0 \mathrm{mg}$ of riboflavin), $6.0 \mathrm{ml} \mathrm{FeSO}_{4}$ solution $(0.120 \%$ by weight) $\mathrm{pH} 7.0$ was used in the study. $100 \mathrm{ml}$ volume of medium in $250 \mathrm{ml}$ of conical flask was inoculated with bacterial suspension and incubated at $37^{\circ} \mathrm{C}$ for 22 hours in anaerobic condition.

\section{Biomass concentration}

An absorbance taken at $600 \mathrm{~nm}\left(\mathrm{~A}_{600}\right)$ was adopted to reflect the biomass concentration since higher absorbance is directly proportional to highest collagenase production using spectrophotometer ${ }^{15,16}$.

\section{Isolation of crude collagenase enzyme}

After fermentation, samples were collected from shake flasks and the Clostridial cells were segregated from broth by centrifugation at $10,000 \mathrm{~g}$ for $10 \mathrm{~min}$. Saturated ammonium sulphate was poured to the clarified fermentation solution to precipitate out the enzyme collagenases. The precipitated crude enzyme further lyophilized by freeze dryer ${ }^{14}$.

\section{Determination of crude collagenase enzyme activity}

Lyophillised enzyme was further dissolved in $0.05 \mathrm{M}$ TES buffer containing $0.36 \mathrm{mM}$ of calcium chloride, $\mathrm{pH} 7.5$ in concentration of $1 \mathrm{mg} / \mathrm{ml}$. Dilutions were prepared as $1 / 10$ and $1 / 20$ in the same buffer solutions.

$25 \mathrm{mg}$ of bovine collagen was weighed into each four test tubes. Two tubes used to serve as blanks which were without enzyme. $5.0 \mathrm{ml}$ of 0.05 M TES buffer containing $0.36 \mathrm{mM}$ of calcium chloride, $\mathrm{pH} 7.5$ was added to these tubes and same incubated at $37^{\circ} \mathrm{C}$ for 15 minutes. Reaction was initialised by addition of $0.1 \mathrm{ml}$ of diluted enzyme solution in appropriate tubes. After 5 hours, collagenase reaction was stopped and followed with withdrawal of $0.2 \mathrm{ml}$ of solution (leaving behind the collagen) and transfer to test tubes previously prepared with $1.0 \mathrm{ml}$ of ninhydrin-citric acid mixture. A blank (collagen incubated with $0.1 \mathrm{ml}$ TES buffer instead of enzyme) was included. Tubes were heated for 15 minutes in a boiling water bath. After cooling, each tube was diluted with $5 \mathrm{ml}$ of $50 \% \mathrm{n}$-propanol. Allowed to stand at room temperature for 
15 minutes and read absorbance at $600 \mathrm{~nm}$. From an L-leucine standard curve micromoles amino acid equivalent to leucine liberated is determined ${ }^{17,18}$.

For optimization studies, the composition of the culture medium viz. trypticase soya broth, proteose peptone and $\mathrm{pH}$ was varied ${ }^{14}$, while buffers, vitamin concentrate amount and time of fermentation were not varied.

\section{Response surface methodology and central composite designs}

A factorial CCD for three factors along with replicates at the centre point was used for optimisation trial studies. The variables used were trypticase soya broth, proteose peptone and $\mathrm{pH}$ each at five coded levels $(-\alpha,-1,0,+1,+\alpha)$, as shown in Table 1 . The relation between the coded forms of the input variable and the actual value of the trypticase soya broth, proteose peptone and $\mathrm{pH}$ are described in equation (1):

$\mathrm{X}_{\mathrm{i}}=\mathrm{X}_{\mathrm{i}}-\mathrm{X}_{0} / \Delta \mathrm{X}_{\mathrm{i}}$

Where $\mathrm{X}_{\mathrm{i}}$ is a coded value and $\mathrm{X}_{\mathrm{i}}$ the actual value of the factor, $\mathrm{X}_{0}$ the actual value of the same variable at the centre point, $\Delta \mathrm{X}_{\mathrm{i}}$ the step change of the variable.

\section{Selection of independent variables}

In this experiment trypticase soya broth and proteose peptone are selected as independent variables as their overall concentration is higher in media, moreover they both serve as carbon as well as nitrogen source of nutrients for growth of clostridium strain. During fermentation process, these nutrients may enhance the biosynthesis of precursors that regulate the metabolism and influence the end product synthesis. The type of nutrients and their concentrations in the medium play an important role in initiating the production of primary and secondary metabolites. Generally, carbon and nitrogen sources present in the medium can enhance the metabolite production while in certain case it also cause toxicity to the microbial cells even at lower concentrations. Hence, not only the cost even the dynamics of nutrients was considered to determine its role as independent variable in this optimisation process ${ }^{19}$. $\mathrm{pH}$ is recognised as a key factor in optimum absorbance as well as for collagenase activity which may vary according to clostridia species, types of substrate and fermentation conditions.

Table 1- Real and coded variables used to optimize fermentation media for C. novyi -NT in central composite design (CCD).

\begin{tabular}{|c|c|c|c|c|c|c|}
\hline \multirow{2}{*}{$\begin{array}{l}\text { Independent } \\
\text { variables }\end{array}$} & \multirow{2}{*}{$\begin{array}{c}\text { Names of } \\
\text { Independent } \\
\text { variables }\end{array}$} & \multicolumn{5}{|c|}{ Levels* } \\
\hline & & Lower (-1) & $\begin{array}{c}\text { Central } \\
(0)\end{array}$ & $\begin{array}{c}\text { Higher } \\
(+1)\end{array}$ & $\begin{array}{c}\text { Axial } \\
(-\alpha)\end{array}$ & $\begin{array}{c}\text { Axial } \\
(+\alpha)\end{array}$ \\
\hline $\mathrm{x}_{1}-\left(\mathrm{g} 100 \mathrm{ml}^{-1}\right)$ & $\begin{array}{l}\text { Concentration of } \\
\text { trypticase soya } \\
\text { broth }(\mathrm{A}) \text { in } g\end{array}$ & 1.0 & 1.5 & 2.0 & 5 & 2.5 \\
\hline $\mathrm{x}_{2}-\left(\mathrm{g} 100 \mathrm{ml}^{-1}\right)$ & $\begin{array}{l}\text { Proteose peptone } \\
\text { (B) in } g\end{array}$ & 4.5 & 5 & 5.5 & 4.0 & 6.0 \\
\hline $\mathrm{x}_{3}$ & $\mathrm{pH}$ of medium $(\mathrm{C})$ & 6.5 & 7.0 & 7.5 & 6.0 & 8.0 \\
\hline
\end{tabular}

The present CCD trial are involved with a total 20 experimental trials that included eight factorial design trials, six axial points trials (two for each variable), and six replication trials of the central points (see Table 2). These three factors, along with 
five coded levels involving 20 experimental runs, were considered for analysis and the received experimental data was employed for a better estimate for further optimisation studies.

The quadratic model in CCD for prediction of the optimal point is addressed as per following equation (2):

$y=b_{0}+\sum b_{i} x_{i}+\sum b_{i i} x_{i}^{2}+\sum b_{i j} x_{i} x_{j}$

where $y$ is known as response variable while b0, bi, bii, bij are the regression coefficients variables and $x i$ and $x j$ are independent variables. Twenty runs, at all possible combinations of the factor levels, were performed to determine the optimal concentration of trypticase soya broth (A), proteose peptone (B) and $\mathrm{pH}(\mathrm{C})$ and to develop a mathematical correlation. All three variables were investigated at low level (-1), zero level $(0)$ and high level $(+1)$, respectively, with $\alpha=1.682$.

\section{Statistical Analysis}

Statistical model analysis was evaluated to determine the analysis of variance (ANOVA) and the quadratic models were constituted as 3D contour plots using Design-Expert® 7 software ${ }^{20,21}$.

\section{RESULTS}

The optimization of different parameters for fermentation proBcess of crude collagenase by $C$. novyi-NT was successfully conducted in at laboratory experiments. Table 2 presents the experimental design of full factorial model (CCD) with the correspondent responses absorbance and collagenase activity. Based on the results, second order polynomial equation obtained as outlined in equation (3) and (4) as follows:

$$
\begin{gathered}
\mathrm{y}_{1}=+0.64+0.048 \times \mathrm{A}+0.10 \times \mathrm{B}-0.081 \times \mathrm{C}-5.250 \mathrm{E}-003 \times \mathrm{A} \times \mathrm{B}-0.026 \times \mathrm{A} \times \mathrm{C} \\
+0.060 \times \mathrm{B} \times \mathrm{C}+0.050 \times \mathrm{A}^{2}+0.015 \times \mathrm{B} 2+0.056 \times \mathrm{C}^{2}
\end{gathered}
$$

and

$\mathrm{y}_{2}=+166.62+0.41 \times \mathrm{A}+24.29 \times \mathrm{B}-17.94 \times \mathrm{C}-50.96 \times \mathrm{A} \times \mathrm{B}+3.90 \times \mathrm{A} \times \mathrm{C}-17.26 \times \mathrm{B} \times \mathrm{C}$

$$
+23.77 \times A^{2}-1.00 \times B^{2}+2.09 \times C^{2}
$$

where $y_{1}$ is the response variable which is representative of biomass concentration in terms of absorbance, $\mathrm{y}_{2}$ is collagenase activity. A is the code for quantity of trypticase soya broth, $\mathrm{B}$ is for proteose peptone, $\mathrm{C}$ is for $\mathrm{pH}$. 
Table 2. Experimental design and result of full model CCD for two responses

\begin{tabular}{|c|c|c|c|c|c|c|c|}
\hline \multirow{2}{*}{ Std order } & \multirow{2}{*}{ Coded A } & \multirow{2}{*}{ Coded B } & \multirow{2}{*}{ Coded C } & \multicolumn{2}{|c|}{ Absorbance } & \multicolumn{2}{|c|}{ Enzyme activity (Units/mg) } \\
\hline & & & & Actual & Predicted & Actual & Predicted \\
\hline 1 & -1 & -1 & -1 & 0.75 & 0.7204 & 120.66 & 120.40 \\
\hline 2 & 1 & -1 & -1 & 0.919 & 0.8793 & 215.56 & 215.34 \\
\hline 3 & -1 & 1 & -1 & 0.824 & 0.781 & 295.5 & 275.71 \\
\hline 4 & 1 & 1 & -1 & 0.941 & 0.8987 & 200.08 & 194.01 \\
\hline 5 & -1 & -1 & 1 & 0.529 & 0.5007 & 116.22 & 120.09 \\
\hline 6 & 1 & -1 & 1 & 0.563 & 0.5455 & 240.27 & 221.79 \\
\hline 7 & -1 & 1 & 1 & 0.812 & 0.8222 & 235.56 & 227.23 \\
\hline 8 & 1 & 1 & 1 & 0.856 & 0.8561 & 142.22 & 133.93 \\
\hline 9 & $-\alpha$ & 0 & 0 & 0.672 & 0.6991 & 235.11 & 233.02 \\
\hline 10 & $\alpha$ & 0 & 0 & 0.847 & 0.861 & 220.52 & 234.41 \\
\hline 11 & 0 & $-\alpha$ & 0 & 0.452 & 0.5123 & 112.81 & 122.97 \\
\hline 12 & 0 & $\alpha$ & 0 & 0.869 & 0.8502 & 202.67 & 204.61 \\
\hline 13 & 0 & 0 & $-\alpha$ & 0.903 & 0.9314 & 210.33 & 202.66 \\
\hline 14 & 0 & 0 & $\alpha$ & 0.647 & 0.6597 & 122.65 & 142.39 \\
\hline 15 & 0 & 0 & 0 & 0.611 & 0.6376 & 150.33 & 227.23 \\
\hline 16 & 0 & 0 & 0 & 0.623 & 0.6376 & 164.08 & 227.23 \\
\hline 17 & 0 & 0 & 0 & 0.672 & 0.6376 & 182.22 & 227.23 \\
\hline 18 & 0 & 0 & 0 & 0.614 & 0.6376 & 158.67 & 227.23 \\
\hline 19 & 0 & 0 & 0 & 0.681 & 0.6376 & 178.17 & 227.23 \\
\hline 20 & 0 & 0 & 0 & 0.632 & 0.6376 & 168.33 & 227.23 \\
\hline
\end{tabular}

Table 3 and Table 4 show the summary of analysis of variance (ANOVA) for quadratic model in case of absorbance while Table 5 and Table 6 show in case of enzyme activity. In both case statistics among the raw R-Squared value, the related Adjusted R-Squared and the Predicted R-Squared can be observed as a decreasing 
trend, and they are most consistent for the quadratic-polynomial model as indicated in Table 4.

In case of absorbance the "Pred R-Squared" of 0.7736 is found as reasonable agreement towards "Adj R-Squared" of 0.9254. This "Adeq Precision" is responsible for measurement of signal to noise ratio. In case of collagenase activity, the "Pred RSquared" of 0.7493 is in appreciable agreement with the "Adj R-Squared" of 0.9141. Signal to noise ratio is measured by "Adeq Precision". This model can be used for navigation of design space. Moreover, smallest PRESS (predicted residual sum of squares) statistic indicates how well the quadratic model fits the data ${ }^{22}$.

Table 4 and Table 6 shows the F-value of 27.18 in case of absorbance and 23.48 in case of collagenase activity which indicates the quadratic model is most significant and the value of "Prob $>$ F" less than 0.05 denoted that the different model terms are also significant. There is only a $0.01 \%$ chance that the F-value large due to noise. The respected lack-of-fit F-value of 2.30 and 1.92 implies that the lack-of-fit is not significant and model terms like $\mathrm{A}, \mathrm{B}, \mathrm{C}, \mathrm{BC}, \mathrm{A}^{2}, \mathrm{C}^{2}$ are found most significant in case of absorbance (Table 3 ) reponse while in case of collagenase activity $\mathrm{B}, \mathrm{C}, \mathrm{AB}, \mathrm{BC}$, $\mathrm{A}^{2}$ (Table 5) model terms found significant ${ }^{19}$.

Table 3. Analysis of variance for response surface quadratic model on the optimization of Absorbance

\begin{tabular}{cccccc}
\hline Source & $\begin{array}{c}\text { Sum of } \\
\text { Squares }\end{array}$ & df & $\begin{array}{c}\text { Mean } \\
\text { Square }\end{array}$ & $\begin{array}{c}\mathbf{F} \\
\text { Value }\end{array}$ & $\begin{array}{c}\mathbf{p} \text {-value } \\
\text { Prob }>\text { F }\end{array}$ \\
\hline Model & $\mathbf{0 . 3 7}$ & $\mathbf{9}$ & $\mathbf{0 . 0 4 1}$ & $\mathbf{2 7 . 1 8}$ & $<\mathbf{0 . 0 0 0 1 *}$ \\
\hline $\mathrm{A}$ & 0.03 & 1 & 0.032 & 21.07 & $0.0010^{*}$ \\
\hline $\mathrm{B}$ & 0.14 & 1 & 0.138 & 91.67 & $<0.0001^{*}$ \\
\hline $\mathrm{C}$ & 0.09 & 1 & 0.089 & 59.30 & $<0.0001^{*}$ \\
\hline $\mathrm{AB}$ & 0.00 & 1 & 0.000 & 0.15 & 0.7100 \\
\hline $\mathrm{AC}$ & 0.01 & 1 & 0.005 & 3.59 & 0.0874 \\
\hline $\mathrm{BC}$ & 0.03 & 1 & 0.029 & 19.12 & $0.0014^{*}$ \\
\hline $\mathrm{A}^{2}$ & 0.04 & 1 & 0.037 & 24.36 & $0.0006^{*}$ \\
\hline $\mathrm{B}^{2}$ & 0.00 & 1 & 0.003 & 2.29 & 0.1615 \\
\hline $\mathrm{C}^{2}$ & 0.05 & 1 & 0.045 & 29.94 & $0.0003^{*}$ \\
\hline Residual & 0.02 & 10 & 0.002 & & \\
\hline
\end{tabular}

R-Squared: 0.9607, Adj R-Squared: 0.9254, Pred R-Squared: 0.7736

* indicates significant values

Table 4. Summary of results for optimization of Absorbance in ANOVA.

\begin{tabular}{ccccc}
\hline Source & Mean square & F value & $\begin{array}{c}\text { p-value } \\
(\text { Prob }>\text { F })\end{array}$ & \\
\hline Model & 0.0410 & 27.183 & $<0.0001$ & Significant \\
\hline Lack of fit & 0.0020 & 2.299 & 0.1911 & non significant* \\
\hline
\end{tabular}

*Non-significant lack-of- fit is good to fit the model. 
Table 5. Analysis of variance for response surface quadratic model on the optimization of collagenase activity

\begin{tabular}{cccccc}
\hline Source & $\begin{array}{c}\text { Sum of } \\
\text { Squares }\end{array}$ & df & $\begin{array}{c}\text { Mean } \\
\text { Square }\end{array}$ & $\begin{array}{c}\text { F } \\
\text { Value }\end{array}$ & $\begin{array}{c}\text { p-value } \\
\text { Prob }>\text { F }\end{array}$ \\
\hline Model & $\mathbf{4 4 0 4 9 . 8 3}$ & $\mathbf{9}$ & $\mathbf{4 8 9 4 . 4 2 5}$ & $\mathbf{2 3 . 4 8}$ & $<\mathbf{0 . 0 0 0 1 *}$ \\
\hline $\mathrm{A}$ & 2.34 & 1 & 2.340 & 0.01 & 0.9177 \\
\hline $\mathrm{B}$ & 8060.07 & 1 & 8060.074 & 38.66 & $<0.0001^{*}$ \\
\hline $\mathrm{C}$ & 4394.86 & 1 & 4394.856 & 21.08 & $0.0010^{*}$ \\
\hline $\mathrm{AB}$ & 20778.43 & 1 & 20778.431 & 99.68 & $<0.0001^{*}$ \\
\hline $\mathrm{AC}$ & 121.91 & 1 & 121.914 & 0.58 & 0.4621 \\
\hline $\mathrm{BC}$ & 2382.92 & 1 & 2382.916 & 11.43 & $0.0070^{*}$ \\
\hline $\mathrm{A}^{2}$ & 8144.70 & 1 & 8144.701 & 39.07 & $<0.0001^{*}$ \\
\hline $\mathrm{B}^{2}$ & 14.47 & 1 & 14.473 & 0.07 & 0.7975 \\
\hline $\mathrm{C}^{2}$ & 63.04 & 1 & 63.038 & 0.30 & 0.5945 \\
\hline
\end{tabular}

R-Squared: 0.9548, Adj R-Squared: 0.9141, Pred R-Squared: 0.7493

* indicates significant values

Table 6. Summary of results for optimization of Collagenase activity in ANOVA.

\begin{tabular}{ccccc}
\hline Source & Mean square & F value & $\begin{array}{c}\text { p-value } \\
(\text { Prob }>\text { F })\end{array}$ & \\
\hline Model & 4894.425 & 23.48 & $<0.0001$ & Significant \\
\hline Lack of Fit & 274.123 & 1.92 & 0.2457 & non significant* \\
\hline
\end{tabular}

*Non-significant lack-of-fit is good to fit the model.

Three dimensional (3D) response surfaces plots were framed as per model equation to find out the level of interaction among the variables and to evaluate the optimum concentration of each factor on maximum biomass density of $C$. novyi-NT sp. in terms of absorbance and collagenase enzyme activity ${ }^{23}$.

Figure 1 shows Effect on biomass in terms of absorbance due to the interactions between trypticase soya broth and proteose peptone. Biomass concentration (absorbance) enhances with increasing soya broth concentration ( $1 \%, \mathrm{w} / \mathrm{v}$ to $2 \%, \mathrm{w} / \mathrm{v})$ and also cause of peptone $(4.5 \%, \mathrm{w} / \mathrm{v}$ to $5.5 \%, \mathrm{w} / \mathrm{v})$.

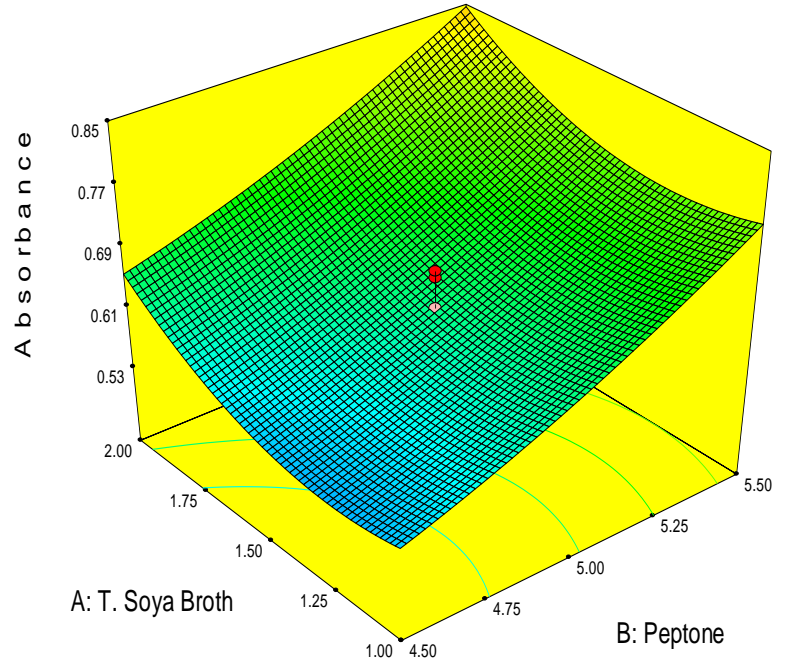

(a)

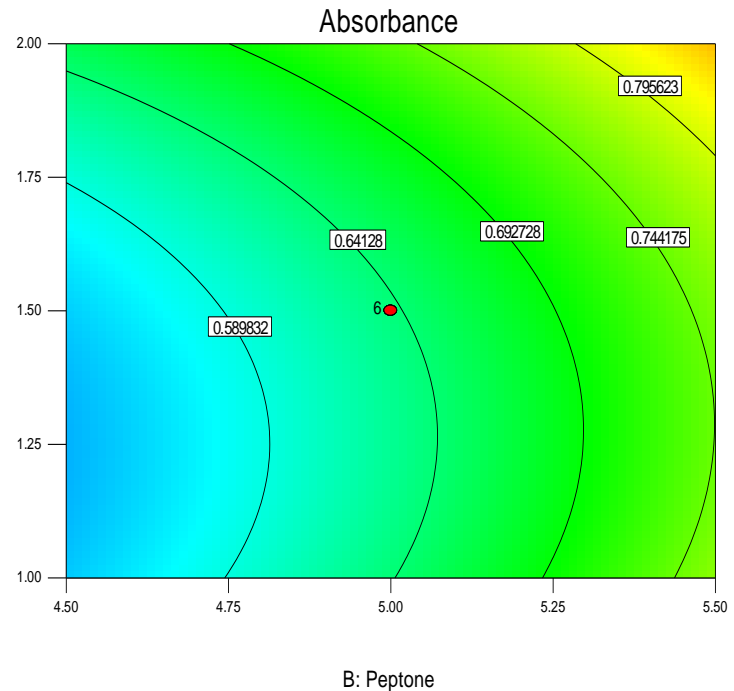

(b)

Figure 1. Response surface curve (a) and contour plot (b) for absorbance, illustrates interactions between trypticase soya broth and peptone concentrations after $22 \mathrm{~h}$ of fermentation. 
In figure 2 Absorbance decreases as we increase the $\mathrm{pH}$ of media from 6.5 to 7.5 but at same time it shows sharp increases while increasing soya broth concentration from $1.0 \%, \mathrm{w} / \mathrm{v}$ to $2 \%, \mathrm{w} / \mathrm{v}$. We also observed decline in absorbance when $\mathrm{pH}$ of media was increased from 6.5 to 7.5 but it was not affected remarkably due to increased concentration of peptone from $4.5 \%, \mathrm{w} / \mathrm{v}$ to $5.5 \%$, w/v as in figure 3 .

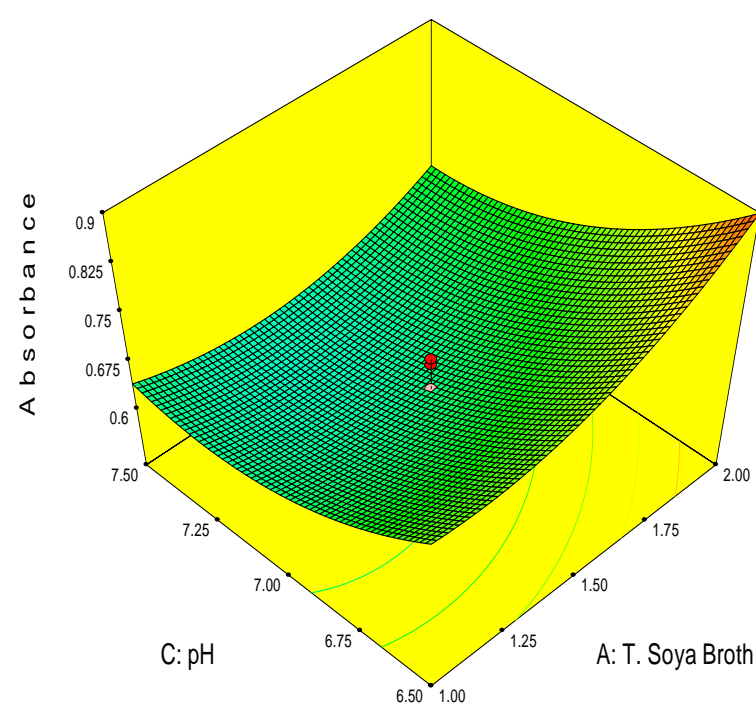

(a)

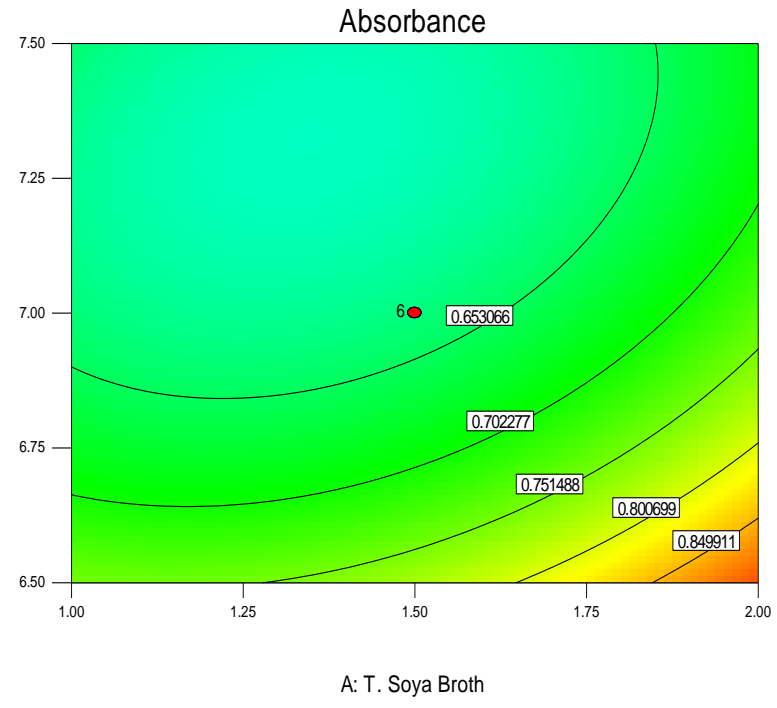

(b)

Figure 2. Response surface curve (a) and contour plot (b) for absorbance, illustrates interactions between $\mathrm{pH}$ and trypticase soya broth concentrations after $22 \mathrm{~h}$ of fermentation.

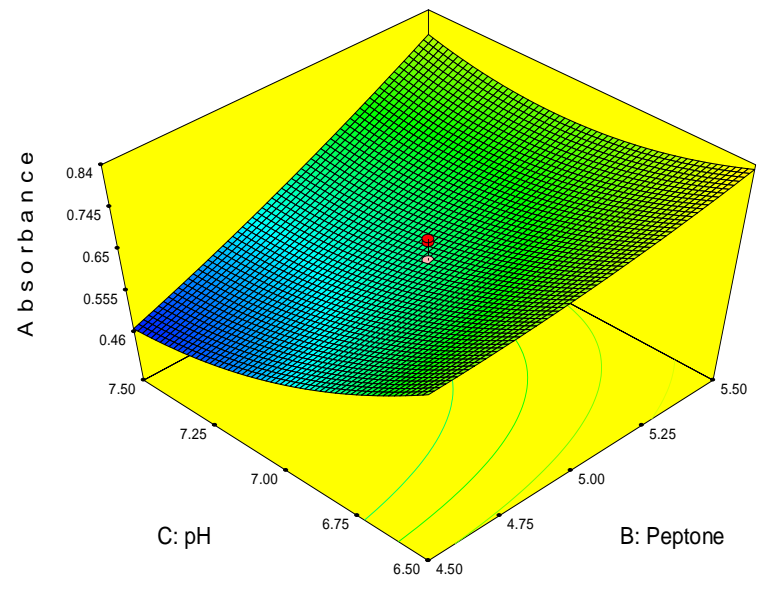

(a)

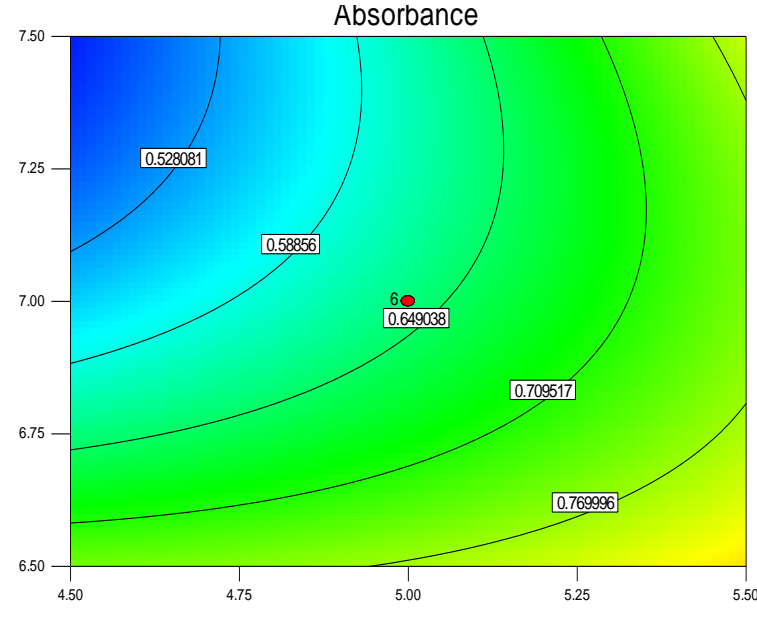

(b)

Figure 3. Response surface curve (a) and contour plot (b) for absorbance, illustrates interactions between $\mathrm{pH}$ and peptone concentrations after $22 \mathrm{~h}$ of fermentation.

Figure 4 illustrates the response curve due to the interactions with trypticase soya broth and peptone as nitrogen source on enzyme activity. Collagenase activity was significantly enhanced with increasing concentration of soya broth $(1 \%$, w/v to $2 \%, w / v)$ and peptone $(4.5 \%$, w/v to $5.5 \%, \mathrm{w} / \mathrm{v})$. 


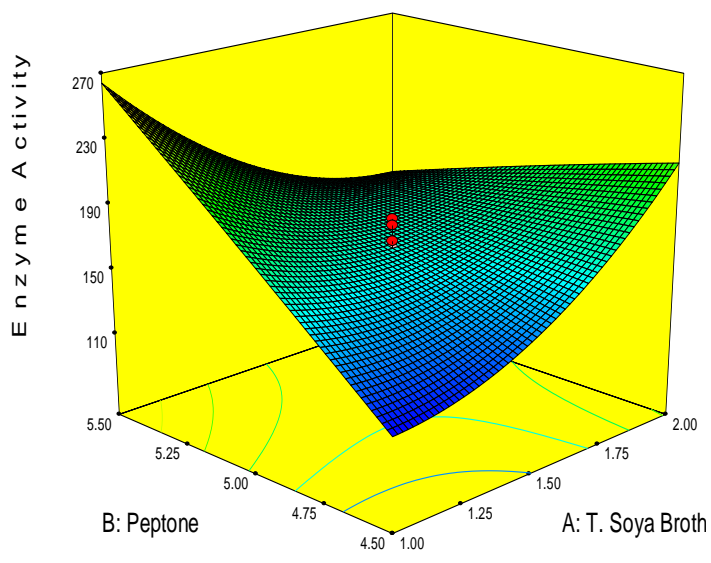

(a)

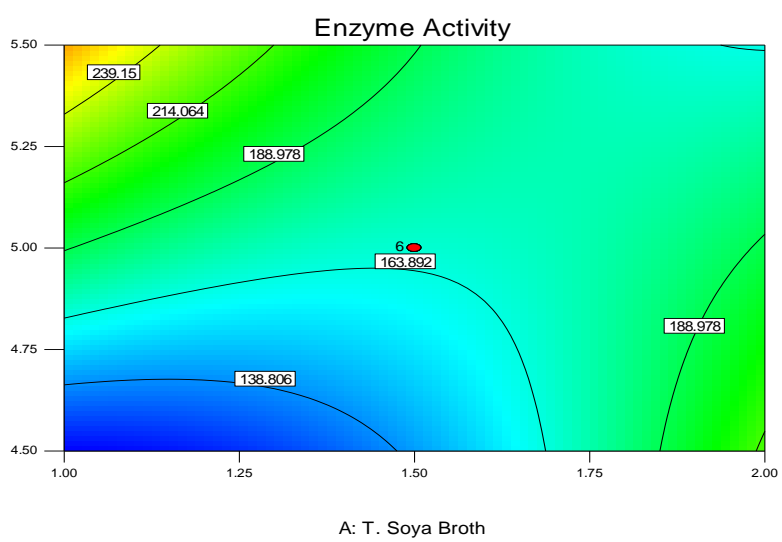

(b)

Figure 4. Response surface curve (a) and contour plot (b) for enzyme activity, illustrates interactions between trypticase soya broth and peptone concentrations after $22 \mathrm{~h}$ of fermentation.

In case of figure 5 enzyme activity was not influenced much due to increase in media $\mathrm{pH}$ from 6.5 to 7.5 but it was observed with sharp increases due to increased concentration of peptone $(4.5 \%, \mathrm{w} / \mathrm{v}$ to $5.5 \%, \mathrm{w} / \mathrm{v})$ in media simultaneously.

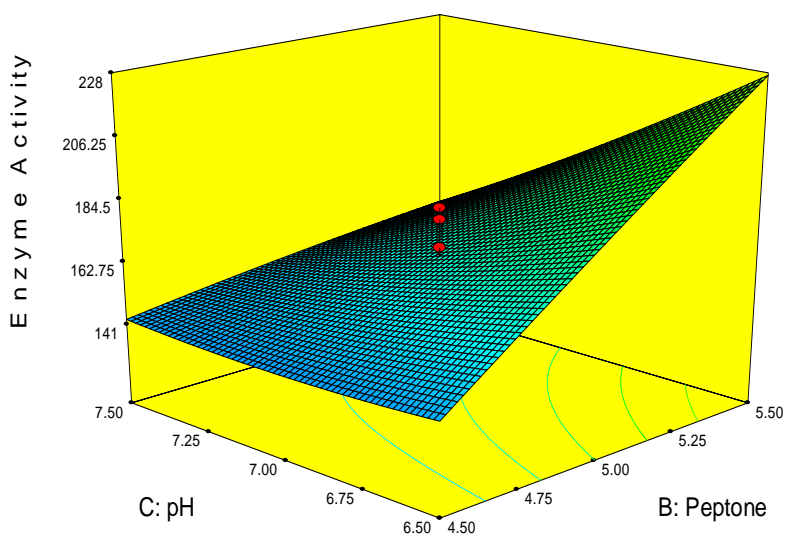

(a)

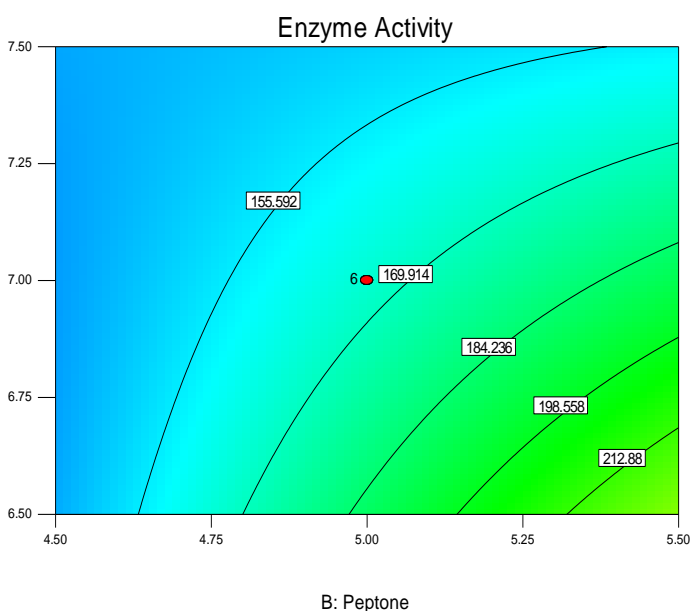

(b)

Figure 5. Response surface curve (a) and contour plot (b) for enzyme activity, illustrating interactions between $\mathrm{pH}$ and peptone concentrations after $22 \mathrm{~h}$ of fermentation.

In case of figure 6, $\mathrm{pH}$ and trypticase soya broth interaction shows, slight decline in collagenase activity as $\mathrm{pH}$ was increased from 6.5 to 7.5 and at same time it was not affected significantly rather it found inappropriate increase in concentration of $1.0 \%$, w/v to $2.0 \%$, w/v due to trypticase soya broth. 


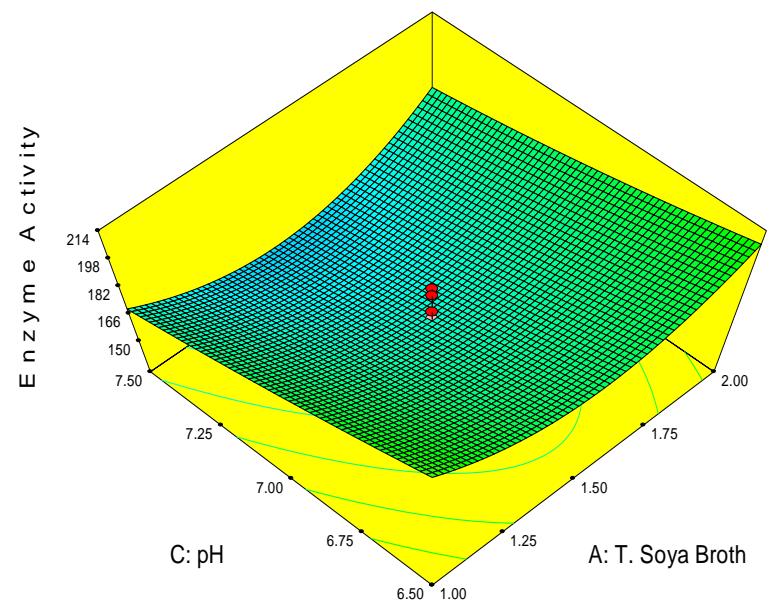

(b)

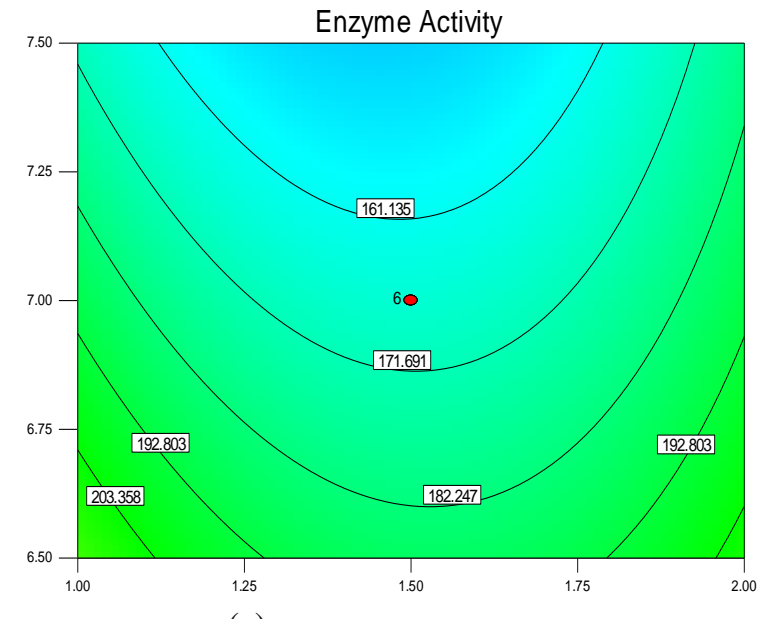

(a)

A: T. Soya Broth

Figure 6. Response surface curve (a) and contour plot (b) for enzyme activity, showing interactions between pH and trypticase soya broth concentrations after $22 \mathrm{~h}$ of fermentation.

Figure 7 (a) and (b) are the perturbation graphs ${ }^{22}$ for absorbance and enzyme activity helps in comparing the effect of each factor at a specific point using space design. The response is shown graphically by varying one factor while other factors remain constant. One factor that was found to affect absorbance and enzyme activity was $\mathrm{pH}$ (curve $\mathrm{C}$ ) followed by trypticase soya broth (curve A).

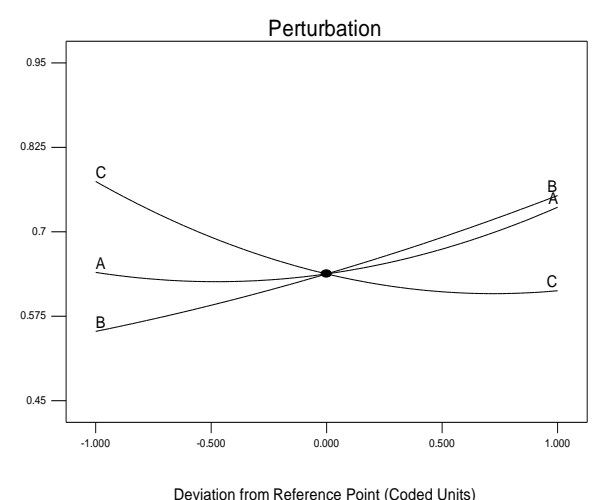

(a)

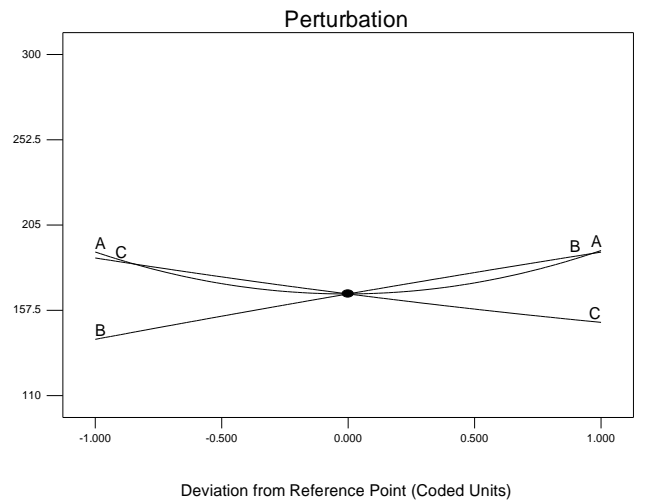

(b)

Figure 7. Perturbation curves indicating interaction of various factors involved in absorbance (a) and enzyme activity (b).

The parity plot is showing a reasonable correlation between observed experimental values and predicted values as in figure 8 (a) and (b) whereas the points cluster around the diagonal, which indicates the good fit of the model, since the deviation between the experimental and predicted values was small ${ }^{23,24}$. 


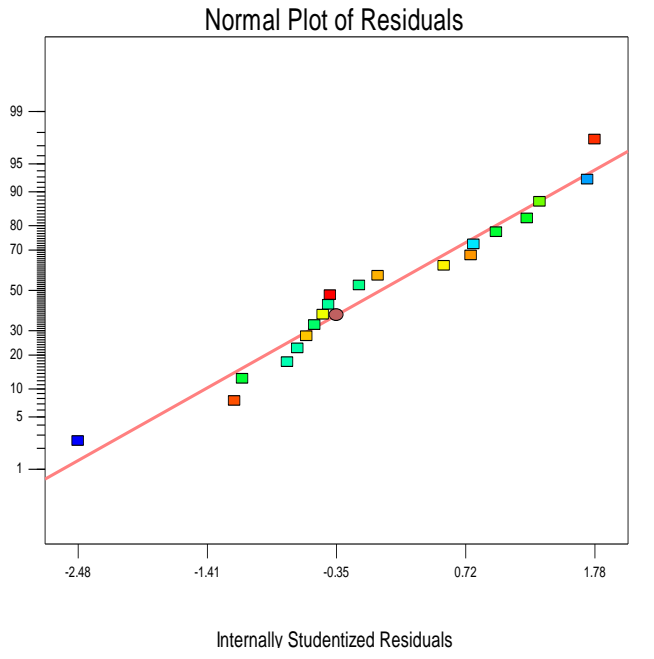

(a)

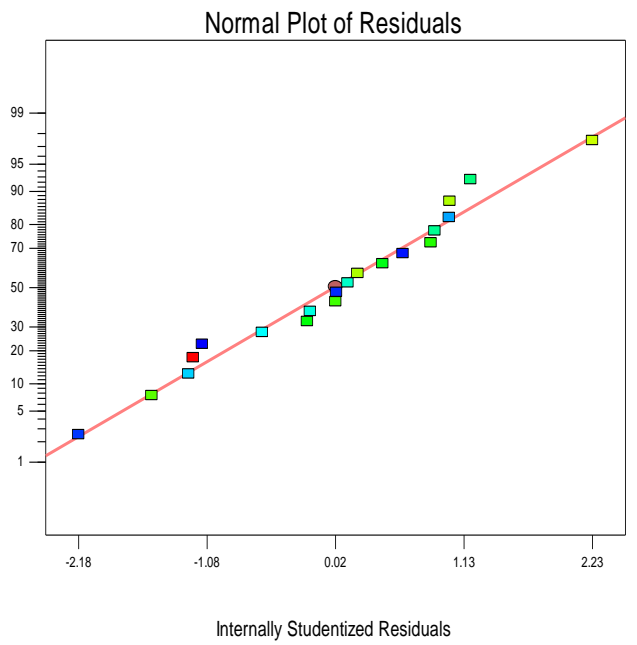

(b)

Figure 8. Parity plot indicating the distribution of experimental vs predicted values of biomass concentration and enzyme activity.

The optimization of these affecting parameters was carried out further in order to experience the enhanced biomass concentration and augmented collagenase activity further as follows. The limit and criterion were set as presented in Table 7.

Table 7. Optimization criteria used in this study with help of CCD quadratic model.

\begin{tabular}{cccc}
\hline \multirow{2}{*}{ Parameter } & \multicolumn{2}{c}{ Limit } & Criterion \\
\cline { 2 - 4 } & lower & Upper & Target \\
\hline $\mathrm{pH}$ & 6.5 & - & Target \\
\hline T. Soya broth in $\mathrm{g}$ & 1 & - & Target \\
\hline Peptone in g & - & 5.5 & Maximize \\
\hline $\begin{array}{c}\text { Absorbance } \\
\text { units/mg }\end{array}$ & 0.452 & 0.941 & Maximize \\
\hline
\end{tabular}

Based on the results in Table 8, the optimized fermentation parameters condition yielded the absorbance and enzyme activity closer to the predicted values. The error ${ }^{23}$ that indicates the deviation between the predicted and the actual values was calculated based on the following equation (5):

Error $=\frac{\text { Actual value }- \text { predicted value }}{\text { actual value }} \times 100$ 
Table 8. Most desirable solution obtained while optimized combination of fermentation parameters for biomass density and enzyme activity.

\begin{tabular}{ccccccccc}
\hline Solution & $\begin{array}{c}\text { T. } \\
\text { noya } \\
\text { Broth } \\
\text { in } \mathbf{~}\end{array}$ & $\begin{array}{c}\text { Peptone } \\
\text { in } \mathbf{g}\end{array}$ & $\mathbf{p H}$ & $\begin{array}{c}\text { Predicted } \\
\text { Absorbance }\end{array}$ & $\begin{array}{c}\text { Actual } \\
\text { Absorbance }\end{array}$ & $\begin{array}{c}\text { Predicted } \\
\text { Enzyme } \\
\text { Activity in } \\
\text { Units/mg }\end{array}$ & $\begin{array}{c}\text { Actual } \\
\text { Enzyme } \\
\text { Activity } \\
\text { in } \\
\text { Units/m } \\
\text { g }\end{array}$ & Desirability \\
\hline 1 & 1.0 & 5.5 & 6.5 & 0.81198 & $0.8309 \pm$ & 305.428 & $\begin{array}{c}298.88 \pm 1 \\
0.0012\end{array}$ & 0.94058 \\
\hline 2 & 1.0 & 5.5 & 6.5 & 0.78863 & - & 282.868 & - & 0.91484 \\
\hline 3 & 1.0 & 5.5 & 6.5 & 0.78809 & - & 282.047 & - & 0.91058 \\
\hline 5 & 1.0 & 5.5 & 6.5 & 0.78763 & - & 282.217 & - & 0.91044 \\
\hline
\end{tabular}

During optimisation of fermentation media for $C$. novyi-NT by central composite design, the software suggested total 5 number of solution. Based on maximum desirability, including highest absorbance and enzyme activity the most appropriate first solution was taken into consideration for further validation.

The most desirable solution obtained by this model was further validated in triplicate to confirm difference between actual and predicted absorbance as well as collagenase enzyme activity. There was no significant difference observed with predicted absorbance (0.81198) and actual absorbance $(0.8309 \pm 0.0012)$. The design has offered optimum activity of enzyme with 298.88 \pm 1.36 Units/mg (Predicted activity: 305.428 Units/mg) in case of crude collagenase obtained from novel bacilli $C$. novyi-NT.

Thus the obtained solution was chosen as most desirable solution as optimised and it is predicted that quadratic model in central composite design of RSM is a suitable model for optimization.

\section{DISCUSSION}

Response surface methodology proved to be a powerful tool in optimizing the fermentation medium for $C$. novyi-NT. In the present study, the experimental results clearly showed that the biomass density of $C$. novyi-NT was rely mainly on the $\mathrm{pH}$ and proteose peptone concentration in media. It is also evident from the results that the trypticase soya broth had marked with inappropriate behaviour especially in optimisation of enzyme activity. The trypticase soya broth is probably involved in enhancing the growth of the bacterium due to presence of various nutritional elements in it. The reason for maintaining of 'target' criterion for all parameters during optimisation of final solution is trypticase soya broth is blamed for its cost and its sluggish involvement in augmenting biomass concentration and enzyme activity as comparison with peptone and $\mathrm{pH}$. While peptone is compatible in linear way and $\mathrm{pH}$ is efficient for overall fermentation even at lower level at 6.5. The optimized fermentation medium for incubating $C$. novyi-NT composed of $1.0 \mathrm{~g}$ trypticase soya broth $(\mathrm{w} / \mathrm{v}), 5.5 \mathrm{~g}$ peptone $(\mathrm{w} / \mathrm{v})$, with maintenance of $6.5 \mathrm{pH}$ excluding remaining factors as unchanged. The C. novyi-NT is being further investigated in our laboratory for its efficiency in collagenase production characteristics and its efficacy in treatment of various fibro-proliferative disorders. 


\section{CONCLUSION}

The evaluation of media components for $C$. novyi-NT was done in order to obtain maximum biomass yield using the central composite design statistical method. Out of eight components required in fermentation process, trypticase soya broth, peptone and maintenance of accurate $\mathrm{pH}$ were found to be the most significant variables and further optimization using response surface optimization technique. The absorbance which is an indication of biomass increased from 0.681 to 0.8309 and $129.12 \mathrm{Units} / \mathrm{mg}$ as collagenase activity with default media parameters; this is reliable increase for this novel bacterial strain. Further isolation and purification of collagenase enzyme obtained from $C$. novyi-NT with special emphasis on inhibitory effects against fibro-proliferative disorders are being carried out in our lab.

\section{ACKNOWLEDGEMENT}

The authors are thankful to University Grants Commission, New Delhi for UGC-BSR fellowship during the tenure. The authors are also thankful to Asst. professor Dr. S. Selvamuthukumar, Dept. of Pharmacy, Annamalai University for his support during the course of present study.

\section{REFERENCES}

1. Rao MB, Tanksale AM, Ghatge MS, Deshpande VV. Molecular and Biotechnological Aspects of Microbial Proteases. Microbiol Mol Biol Rev. 1998; 62(3):597-635.

2. Hamzeh A, Abbasali R, Sedigheh Z, Navid DD, Therapeutic applications of collagenase (metalloproteases): A review. Asian Pac J Trop Biomed 2016; 6(11): 975-981.

3. Orr JS, Kennedy AJ, Hasty AH. Isolation of Adipose Tissue Immune Cells. J Vis Exp. 2013; 75:50707.

4. Sharma KM, Rajesh K, Surbhi P, Ashwani K. Microbial alkaline proteases: Optimization of production parameters and their properties. J Genet Eng Biotechnol. 2017; 15: 115-126

5. Xinghao Y, Xiao X, Dan L, Ribang W, Cuiling W, Jiang Z, et al. Optimization of Collagenase Production by Pseudoalteromonas sp. SJN2 and Application of Collagenases in the Preparation of Antioxidative Hydrolysates. Mar Drugs. 2017; 15: 377-382.

6. Lima, CA, Viana M, Neto BB, Lima Filho JL, Carneiro-da-Cunha MG. and Porto ALF. Fermentation medium for collagenase production by Penicillium aurantiogriseum URM4622. Biotechnol Progress. 2011; 27: 1470-1477.

7. Walter J, Sandoval E, Mari C, Jose M, Bruno B. Inoculum optimization of Clostridium beijerinckii for reproducible growth. FEMS Microbiol Lett. 2015; 362: 1-7.

8. Said MD, Suzanne MB, Abdel EG, Su-Ling B and Deepika D. Extraction and Purification of Collagenase Enzymes: A Critical Review. Am J Biochem Mol Biol. 2010; 6 (4): 239263.

9. Nandy SK. Bioprocess Technology Governs Enzyme Use and Production in Industrial Biotechnology: An Overview. Enz Eng. 2016; 144 (5): 1-5.

10. Hegde S, Bhadri G, Narsapur K, Koppal S, Oswal P, Statistical Optimization of Medium Components by Response Surface Methodology for Enhanced Production of Bacterial Cellulose by Gluconacetobacter persimmonis. J Bioprocess Biotech. 2013; 142(4): 1-5.

11. Singh V, Haque S, Niwas R, Srivastava A, Pasupuleti M, Tripathi CKM. Strategies for Fermentation Medium Optimization: An In-Depth Review. Front Microbiol. 2016; 2087 (7):1-10.

12. Guillaume E. Vanot, Michelle S. Experimental Design in Microbiology Methods in Biotechnology. In: Barredo JL, editor. Microbial Processes and Products. Totowa: Humana Press Inc.; 2005. p. 25-40.

13. Navid N, Manica N, Ahmad G, Younes G. Computational analysis of collagenase from different Vibrio, Clostridium and Bacillus strains to find new enzyme sources. Trends Pharm Sci. 2015; 1(4): 213-222.

14. Angelo JC, Hempstead, Edwin HW, inventors; Agricultural Biologicals Corporation, Lynbrook, assignee. Process for producing collagenase. United States patent 3705083. 1972 Dec 5. 
15. Munir RI, Schellenberg J, Henrissat B, Verbeke TJ, Sparling R. Comparative Analysis of Carbohydrate Active Enzymes in Clostridium termitidis CT1112 Reveals Complex Carbohydrate Degradation Ability. PLoS ONE. 2014; 9(8): e104260. 1-13.

16. Stevenson K, Alexander F. McVey, Ivan BN, Clark, Peter S. General calibration of microbial growth in microplate readers. Sci Rep. 2016; 6 (38828): 1-7.

17. Hossam H, Extracellular collagenase from Rhizoctonia solani: Production, purification and characterization. Indian J Biotechnol. 2008; 7: 333-340.

18. Said MD, Suzanne MB, Abdel EG, Su-Ling B, Deepika Dave. Extraction and Purification of Collagenase Enzymes: A Critical Review. Am J Biochem Biotechnol. 2010; 6 (4): 239263.

19. Singh V, Haque S, Niwas R, Srivastava A, Pasupuleti M, Tripathi CKM. Strategies for Fermentation Medium Optimization: An In-Depth Review. Front Microbiol. 2016;7:2087.

20. Henderson B. Introduction to Response Surface Methods. Minneapolis: Stat-Ease Inc. "updated in 2012"; "accessed in December 2016". Optimal (Custom) Designs, Part 2. Available from: http://www.statease.com/webinar.html.

21. Myers RH, Montgomery D. The analysis of second-order response surfaces. In: Zentralblatt M, editor. Response Surface Methodology: Process and Product Optimization Using Designed Experiments. $4^{\text {th }}$ Edition. New York: Wiley; 2012.

22. Anderson MJ, Whitcomb PJ. Central composite design: stars added -RSM show begins. In: Anderson MJ editor. RSM Simplified, Optimizing Processes Using Response Surface Methods for Design of Experiments. New York: Productivity Press; 2005.

23. Carroll C, Paul T. Engineering Statistics Handbook. Gaithersburg: National Institute of Standards and Technology. "Updated in October 2016"; "accessed in December 2016" Response surface model example. Available from http://www.itl.nist.gov/div898/handbook/index.htm

24. Siti RM, Husaini A, Cirilo NH, Hasnain H, Nurshikin S, Hairul AR. Application of Response Surface Methodology for Optimizing Process Parameters in the Production of Amylase by Aspergillus flavus NSH9 under Solid State Fermentation. Braz Arch Biol Technol. 2016; 59: e16150632. 